\title{
Introducing Componential Analysis into a Russian Language Course ${ }^{1}$
}

\section{Использование компонентного анализа при обучении русскому языку как иностранному}

\author{
Marina Vazanova \\ (Bratislava, Slovakia)
}

\begin{abstract}
:
The ability to accurately express thoughts and feelings is formed by students most successfully when they have developed an attention to the semantics of any textual meaning of the word and its collocational patterns. This article shows how students can master the techniques of a componential analysis of lexical units. Highlighting not only core, peripheral, specific, species, connotative, potential and probability components, but also modified and actual, uncharged (inactive) and significant, induced and supported, or charged and muted, explicit and implicit, antonymous and evaluative components extend the boundaries of using componential analysis. The study and description of the content words indicate the possibility of componential variation in the structure of words meanings.
\end{abstract}

\section{Key words:}

componential analysis; context; main and peripheral components; modification of the meaning of the word; actualization of components used in the text

1 The paper was edited by Thomas Collins MA (Cantab). 
The design of any professional course should be structured to ensure the formation of appropriate professional skills. Two of the most difficult skills to learn for future specialists in the field of Russian language studies are:

- a holistic scientific understanding of how to use the language system

- the ability to analyze its multi-level units and to accurately and appropriately use units of language in speech

Thoughts and feelings are expressed through speech. When using a foreign language, the creation of a collection of words may not accurately represent the intended thoughts and feelings. To avoid this, close attention must be paid to the semantic of every single word and its collocational probabilities. To learn how to deliberately and precisely choose the words and prepare a coherent text we teach students using the method of componential analysis of words in text. In the past ten years, when training Russian language teachers, we have placed much greater emphasis on this technique.

The goal of this paper is to illustrate how componential analysis could be introduced into a typical Russian language course.

A considerable amount of work has been done on the componential structure of the lexical meaning of words by researchers V. G. Gak, Yu. N. Karaulov, N. G. Komlev, I. A. Sternin, A. A. Ufimtseva, etc. The method of componential analysis is based on the premise that the meaning of each word consists of components. The meaning of a word can be analysed through structured sets of semantic features or components. The components show not only intersystem connections (component-lexical meaning-antonyms, synonyms etc.), but also the connections between units of different linguistic systems. Sometimes even a morpheme can change the grammatical or lexical meaning of a word.

For example, in the word деревь-я (treеs) the component 'множественность' (multiplicity) is contained in the morpheme $-я$.

Many morphemes have content that is transmitted in a specific component. For example, the prefix до- has component 'завершенность действия' ('completed action') (до-бежать-to reach a destination, до-сидеть-to sit out), and the prefix без- brings a semantic feature denial-component 'не / не имеющий' 'no / not having' (cf:: безграничный-limitless, беззаботный-carefree).

When we teach students new vocabulary, we must include knowledge about the componential structure of the word. This will help them accurately select the right words when creating or interpreting discourse.

For example, in order to identify the collocational possibilities of the word steep (крутой), we perform a syntagmatic analysis of the meaning of this word in the phrase "steep rise" (Steep slope, steep turn, and immediately a steep rise, and at once a steep turn, followed by a steep slope, etc. Vasily Aksyonov, Round-the-clock non-stop / 
Крутой уклон, крутой вираж, и сразу крутой подъём, и сразу крутой вираж, а за ним сразу крутой уклон и так далее. Василий Аксенов. Круглые сутки нон-стоп). To this end, we define the definitions of the words steep and rise (крутой и подъем) and, on the basis that there are of common lexical and grammatical components in these words meanings, we prove their ability to combine to organize the phrase: steep ("with a sharp, sudden change of direction" /"с резким, внезапным изменением направления") rise ("a place in the path where the road rises upward" / "место в пути, где дорога поднимается кверху"). The components 'direction' ('направление')-“line of motion, path of development" / “линия движения, путь развития" and 'path'-"place, line in space..." / 'nуть'-“место, линия в пространстве..." create a semantic and grammatical connection and coordination (as Carter Ronald says 'keep company' [CARTER 2012, 66] with each other, have high probability of being found near each other) in the phrase steep rise / крутой подъем.

In an analogous way we could find that there is a reasonable probability of using "interesting" and "book" in the same sentence. The collocational probability is high. They have common components. In contrast it would be highly unlikely that "tasty" and "book" appear together!

Even if students are not aiming to become linguistic experts and simply wish to learn the language then the methods of componential analysis should still be applied when teaching them. Simplistically this means that words should only be introduced in context. The context can best be explained by presenting multiple examples of different texts which include the new word. Some examples should be presented with the word with multiple new examples being introduced in subsequent lessons.

The context can predetermine which meaning (or realisation) of the word is appropriate in any specific text. The text is able to modify the meaning of the word, giving it a specific personal or individual meaning. This, in essence, implies that in the text words concretize their meanings by virtue of their connection and correlation with other words. They enter into meaningful relationships with other words around them. The influence of context can be dramatic in how it changes the meaning of a word.

The methodology for performing componential analysis of the meaning of a word is based on a phased analysis of the semantic structure of the meaning of the word and its context partners. To begin with, we specify the meaning of the word in a dictionary. Then we analyze its textual environment. Examples include; the company the word has, how single words operate in a lexical environment with other words, their relations with other words in accordance with the author's intention (in accordance with the particular meaning suggested by the context).

Based on the set of linguistic data about connections and relations of words in the text, as well as on represented characteristic of the structure of lexical meaning, we 
try to show how the method of componential analysis works on literary texts. In particular, we consider the case of modification of the meaning of the word blind (слепой) through the actualization of components used in the text.

The following example is taken from "White Nights" (Fedor Dostoevsky)

1. Да кто же вы такой, объяснитесь! Постойте, я догадываюсь: у вас, верно, есть бабушка, как и у меня. Она слепая и вот уже целую жизнь меня никуда не пускает, так что я почти разучилась совсем говорить. А когда я нашалила тому назад года два, так она видит, что меня не удержишь, взяла призвала меня, да и пришпилила булавкой мое платье к своему - и так мы с тех пор и сидим по целым дням; она чулок вяжет, хоть и слепая; а я подле нее сиди, шей или книжку вслух ей читай - такой странный обычай, что вот уже два года пришпиленная... (Ф. Достоевский. Белые ночи).

"Who are you then? Explain yourself! Stay, I guess: most likely, like me you have a grandmother. She is blind and will never let me go anywhere, so that I have almost forgotten how to talk; and when I played some pranks two years ago, and she saw there was no holding me in, she called me up and pinned my dress to hers, and ever since we sit like that for days together; she knits a stocking, though she's blind, and I sit beside her, sew or read aloud to her-it's such a queer habit, here for two years I've been pinned to her."

These fragments of texts using the word слепой (blind) reveal more information than a literal dictionary meaning. In addition there are potential components 'helplessness, selfishness, fear of loneliness' that weaken the significance of the main component 'unseeing' ('невидящий').

When a student starts learning russian it is too early to introduce these linguistic concepts. Initially the 'groundwork' is laid by introducing vocabulary "in context" as described above.

Towards the end of A1 level the importance of morphemes can be explained (for example see деревь-я (trees) above).

At A2 level a few selected examples can be introduced-but without huge detail. The example of слепой (blind) above would be typical.

However by level $\mathrm{B}_{2}$ a significant portion of the course should be dedicated to examining texts in detail. These texts can be selected to highlight the importance of componential analysis in understanding the true meaning of words in context.

To illustrate this I have selected six additional texts with the word слепой (blind). The text would be discussed in class and a typical analysis is outlined below:

2. По утрам, если солнце приглашало меня, я ездил за город купаться. У конечной остановки трамвая, на зеленой скамье, проводники - коренастые, в огромных тупых сапогах - отдыхали, вкусно покуривая, и потирали изредка тяжелые, пропахнувшие металлом руки, глядя, как рядом, вдоль самых рельс, человек 
в мокром фартуке поливает иветущий шиповник, как вода серебряным гибким веером хлещет из блестящей кишки, то летая на солнце, то наклоняясь плавно над трепещущими кустами. Я проходил мимо них, зажав под мышкой свернутое полотенце, быстрым шагом направлялся к опушке леса; там частые и тонкие стволь сосен, шероховато-бурые внизу, телесного ивета повыше, были испещрены мелкими тенями, и на чахлой траве под ними валялись, как бы дополняя друг друга, лоскутки солнца и лоскутки газет. Внезапно небо весело раздвигало стволь; по серым волнам песка я спускался к озеру, где вскрикивали да поеживались голоса купавшихся и мелькали на светлой глади темные поплавки голов. На пологом скате навзничь и ничком лежали тела всех оттенков солнечной масти - иные еще белье с розоватым крапом на лопатках, иные же жаркие, как мед или цьвет крепкого кофе со сливками. Я освобождался от рубашки, и сразу со слепою нежностью наваливалось на меня солнце (В. Набоков. Драка).

3. Однако, как радость и счастие делают человека прекрасным! как кипит сердие любовью! Кажется, хочешь излить все свое сердие в другое сердие, хочешь, чтоб все было весело, все смеялось. И как заразительна эта радость! Вчера в ее словах было столько неги, столько доброты ко мне в сердие... Как она ухаживала за мной, как ласкалась ко мне, как ободряла и нежила мое сердще! О, сколько кокетства от счастия! А я... Я принимал все за чистую монету; я думал, что она...

Но, боже мой, как же мог я это думать? как же мог я быть так слеп, когда уже все взято другим, все не мое; когда, наконеи, даже эта самая нежность ее, ее забота, ее любовь.. да, любовь ко мне, - была не что иное, как радость о скором свидании с другим, желание навязать и мне свое счастие?.. Когда он не пришел, когда мы прождали напрасно, она же нахмурилась, она же заробела и струсила. Все движения ее, все слова ее уже стали не так легки, игривы и весель. И, странное дело, - она удвоила ко мне свое внимание, как будто инстинктивно желая на меня излить то, чего сама желала себе, за что сама боялась; если б оно не сбылось (Ф. Достоевский. Белые ночи).

But how fine joy and happiness makes any one! How brimming over with love the heart is! One seems longing to pour out one's whole heart; one wants everything to be gay, everything to be laughing. And how infectious that joy is! There was such a softness in her words, such a kindly feeling in her heart towards me yesterday... How solicitous and friendly she was; how tenderly she tried to give me courage! Oh, the coquetry of happiness! While I... I took it all for the genuine thing, I thought that she...

But, my God, how could I have thought it? How could I have been so blind, when everything had been taken by another already, when nothing was mine; when, in fact, her very tenderness to me, her anxiety, her love... yes, love for me, was nothing else but joy at the thought of seeing another man so soon, desire to include me, too, in her happiness?. (Fedor Dostoevsky. White Nights) 
4. Чего вы боитесь? Зачем вы бросили мою руку? - сказала она, подавая мне ее опять. - Ну, что же? мы встретим его вместе. Я хочу, чтоб он видел, как мы любим друг друга.

- Как мы любим друг друга! - закричал я.

“О Настенька, Настенька! - подумал я, - как этим словом ты много сказала! От этакой любви, Настенька, в иной час холодеет на сердие и становится тяжело на душе. Твоя рука холодная, моя горячая как огонь. Какая слепая ты, Настенька!.. О! как несносен счастливый человек в иную минуту! Но я не мог на тебя рассердиться!..”(Ф. М. Достоевский. Белые ночи).

"What are you afraid of? Why did you let go of my hand?" she said, giving it to me again. "Come, what is it? We will meet him together; I want him to see how fond we are of each other."

"How fond we are of each other!" I cried. ("Oh, Nastenka, Nastenka," I thought, "how much you have told me in that saying! Such fondness at certain moments makes the heart cold and the soul heavy. Your hand is cold, mine burns like fire. How blind you are, Nastenka!.. Oh, how unbearable a happy person is sometimes! But I could not be angry with you!" (Fedor Dostoevsky. White Nights)

5.

\section{ДОБРЫЙ СОВЕТ}

Давайте пить и веселиться,

Давайте жизнию играть,

Пусть чернь слепая суетится,

Не нам безумной подражать.

Пусть наша ветреная младость

Потонет в неге и вине,

Пусть изменяющая радость

Нам ульгнется хоть во сне.

Когда же юность легким дымом

Умчит веселья юных дней,

Тогда у старости отымем

Все, чтоо отымется у ней.

\section{(А. С. Пушкин)}

6. Утро двадиать девятого сентября сорок первого года начиналось в Москве уныло, нехотя. Ночью сыпал нудныцй, сиротский дождичек, рассвет никак не мог пробиться сквозь низкие, разбухшие облака, разогнать влажный сумрак. Зашторенные окна не пропускали свет, казались слепыми. Глухо стучали сапоги патрулей, в подъездах сутулились фигуры жильцов - дежурных по 
ПВО, с бульваров и набережных тянулись к угрюмому небу тросы аэростатов заграждения (И. Старинов. Записки диверсанта).

7.

\section{АМУР И ГИМЕНЕЙ}

Сегодня, добрые мужья,

Повеселю вас новой сказкой.

Знавали ль вы, мои друзья,

Слепого мальчика с повязкой?

Слепого?.. Вот? Помилуй, Феб!

Амур совсем, друзья, не слеп:

Но шалуну пришла ж охота,

Чтоб, людям на смех и назло,

Его безумие вело.

Безумие ведет Эрота:

Но вдруг, не знаю почему,

Оно наскучило ему.

Взялся за новую затею:

Повязку с мильх сняв очей,

Идет проказник к Гименею...

А что такое Гименей?

Он сын Вулкана молчаливыцй,

Холодньцй, дряхльй и ленивьй,

Ворчит и дремлет цельий век,

А впрочем, добрый человек

Да нрав имеет он ревнивыци.

От ревности печальный бог

Спокойно подремать не мог;

Все трусил маленького брата,

За ним подсматривал тайком

И караулил супостата

С своим докучным фонарем.

Вот мальчик мой к нему подходит

И речь коварную заводит:

«Развеселися, Гименей!

Ну, помиримся, будь умней!

Забудь, товарищ мой любезнььй,

Раздор смешной и бесполезный!

Да только навсегда, смотри! 
Возьми ж повязку в память, милььй,

А мне фонарь свой подари!»

И что ж? Поверил бог унылььй.

Амур от радости прьгнул,

Ина глаза со всей он сильь

Обнову брату затянул.

Гимена скучные дозоры

С тех пор пресеклись по ночам;

Его завистливые взорь

Теперь не страшны красотам;

Спокоен он, но брат коварныци,

Шутя над честью и над ним,

Войну ведет, неблагодарный,

С своим союзником слепым.

Лишь сон на смертных налетает,

Амур в молчании ночном

Фонарь любовнику вручает

И сам счастливца провожает

К уснувшему супругу в дом;

Сам от беспечного Гимена

Он охраняет тайну дверь...

Пойми меня, мой друг Елена,

И мудрой повести поверь!

(А. С. Пушкин)

In the second text the word слепой (blind) could be interpreted through the main component 'reckless acting or done without reasonable cause' ('безрассудньй, действующий или совершающийся без разумного основания') [OŽEGOV, ŠVEDOVA 2006]. In fact the potential component 'indiscriminately' ('без разбора') becomes important. This component is essential for its semantic compatibility with its context partners-in this case the words tenderness, freed (нежность, освобождался).

As a result the word blind becomes synonymous with the words all-embracing, warm. Here we can say that the word is losing its "separateness" (отдельность) [STEPANOVA 1998] and autonomy, and enters into communications and relations with other units of the text, which significantly alter its quality.

Comparative analysis of the third and fourth textual fragments shows that, using structurally identical sentences, the word blind has its own (different in each case) set of modifications of meaning: if in the first case, the component 'unseeing' 
('невидящий) of textual meaning "does not see that happening behind him, taken at face value") is not relevant (actual are peripheral component 'jealousy', 'suspicious', 'despair', but it is present, then the blind in the second text is "seeing", but "sees what he wants to see, what he is thinking about". Entered in "antonym context" ("антонимический контекст") [ČERNJAK 1997], the word blind from the second text actualizes in its meaning the opposite probability components 'what wants to see'- 'what is in reality' and potential components 'sorry'-'irritation'. Highlighted in the text components, are aimed at solving certain communication problems, that in turn, requires that the partners have common components: grows cold heart, cold hand, sick at heart, and a sort of love unbearable, angry (холодеет на сердие, холодная рука, тяжело на душе и этакая любовь, несносен, рассердиться). Therefore, in the first case, the word blind will match the textual synonym naive, trusting, and in the second, being in the non-acquaintance.

As we can see, the word blind has a relatively broad combinability, and its meanings are not limited by phraseology and by syntactic connectedness. However, this word can be rather uninformative without the nearest contextual partners. This we see, in particular, in the fifth text. Here we explain the close semantic coherence of combination blind mob (слепая чернь) by phraseological-bound meaning of its lexical items. Therefore, identifying their meaning was made possible mainly thanks to a textual ratio of this combination with the antonym life (life-blind mob (death)). At the same time we should not underestimate the role of the textual semantic features bustling (суетится), сrаzу (безумная), old age-youthfulness (старость-младость), take away (отымем), which not only actualize word meaning "blind-indiscriminate", but also highlight the evaluative components of its meaning.

The sixth text, relating to the publicistic style, could serve as another indicator of the extension of collocational ranges of the word blind. The peculiarity of the use of words in the text is due to the so-called "violation of conceptual compatibility of word forms" (“нарушением понятийной сочетаемости словоформ”) [VALGINA 2003]. In fact, if the free compound words blind curtains (слепье шторы) is considered incorrect, although the components of their dictionary meanings overlap, are combined in the component 'not seen', then in the sixth text such combination is justified, to some extent predictable, and even markedly: as the next "contextual partners" to the analyzed word blind are the words sadly, reluctantly, tedious, orphan, dusk, curtained, hollowly, stooped, dragged, sullen (уныло, нехотя, нудный, сиротский, сумрак, зашторенные, глухо, сутулились, тянулись, угрюмому), containing connotative meanings. Semantic features 'closed', 'indifferent', 'closed to others' are the central organizing element of these words. It is these charged components require a presence of the word blind as their "contextual partner". Thus, thanks to its collocational properties this word with a high probability predicts the appearance not only it's direct, "closest" contextual 
partner, but also through it other members of the utterance [NORMAN 1994]. In short, we can explain and predict the choice of a lexical unit through the component composition of a single word.

A striking example of the manifestation of the duality of the word in the literary work is the seventh text. Here the world blind has the same meaning as in the dictionary, but at the same time it gets additional meaning as a result of being associated with particular cultural contexts and full content of the literary work [SOLGANIK 2002, 196]. Indeed, at first glance, the same word as in everyday speech, the word blind in the art text has a wider semantic capacity. This can be explained partly by the peculiarities of the semantic structure of the textual meaning of a word. Semantic structure of the word blind, along with the main component of 'not seeing', contains a significant (for this text) component 'calm': here blind is not only a "blindfolded", but also "having no opportunities", and most importantly, "the desire to poach in other people's business", "non-interfering".

The author's intention can be revealed this way. The text is constructed using the word meaning probabilities (that is, by embedded components (наведением сем), by I. A. Sternin terminology [STERNIN 1985]): Cupid as he is blind (blindfolded), "occupied only by his business and not interfere in other people's business," and Hymen - with a lantern-"sees all that prevents him to live peacefully", and that's why he is jealous, envious, sad and restless. But as soon as they tied a blindfold over Hymen eyes, he ceased to interfere in the affairs of others. Therefore, here the core of meaning of 'not seeing' is the "unnecessary element" (ненужная деталь) [KUBRJAKOVA 1981], which can be eliminated easily as a matter of course, and the probability components, included by the author in the text to create an art image, come to the fore.

Teaching Russian in this way firstly introduces the student to a wide variety of texts. However the intention is to highlight the importance of context and being able to identify when a words meaning is significantly altered as this is a common occurrence in russian texts. Although I have endeavoured to explain the analysis in English in this paper, in practise it is far better to explain difficult concepts of a language in that language. Of course students require a certain level to be able to comprehend and this is why this sort of detailed analysis is only introduced at B2 level. In Russia, language qualifications (Russian as a foreign language) are standardised through the examinations of the Russian State education department. At each level comprehension of a text is expected. To score well at $\mathrm{B} 2$ level requires understanding of componential analysis.

Further, the most effective way to teach these concepts is through group discussion and group analysis. The explanation should not be in the form of a lecture from the teacher. Consequently an environment is created where the students converse, discuss and argue in Russian. 
Newspapers are also a useful source for texts. Newspaper articles reflect the current state of the Russian language. Further, by using current affairs, students are typically more 'engaged' and, being keen to express their opinions accurately, unconsciously put more effort into their selection of words. The teacher has the opportunity to summarise the point that has been made (as she heard it). In the event that the student meant something different then they can correct and learn why their choice of words was not completely accurate.

For example I once gave students a task to review a newspaper article "A citizen of Cheboksary proposes legalisation of marijuana". The question posed was to consider if the article suggests advantages of using certain drugs. Are certain drugs less dangerous and therefore OK to use. After studying the article, in particular, the fragment "... There is a myth that marijuana is dangerous for society. In fact, it is quite the contrary. By the toxicity the hemp is much safer than tobacco and alcohol...", the students were unanimous in the opinion that the article champions the use not only of hemp, but also of tobacco and alcohol. In order to substantiate their point of view, they conducted a componential analysis of the keyword safe.

Lexicographic description of the word safe (1. Not threatening with danger // Not harming, harmless (Dictionary of T. F. Efremova), Not threatening with danger, protecting from danger (Dictionary of S. I. Ozhegov), Not causing harm, harmless (Dictionary of synonyms under the editorship of Z. E. Aleksandrova) / (безопасный: 1. Не грозящий опасностью // Не причиняющий вреда; безвредный. [JEFREMOVA 200o]; Не угрожающий опасностью, защищающий от опасности [OŽEGOV, ŠVEDOVA 2006, 41]; Неопасный, безвредный [ALEKSANDROVA 2001, 26] has already showed the presence the active component "not causing harm" in it. Based on the content of the dictionary definitions of this word, the reader can assume that "alcohol and hemp are safe". But, used in the comparative form, the adjective safer (безопаснее) contains in its meaning, besides the component 'nо' ('не') the component 'mоге' ('более'), and the adverb significantly/значительно adds to the structure of the meaning of the word safer the additional component 'more' ('более'). Therefore, readers can interpret the content of the text fragment as follows: the use of alcohol, tobacco and hemp does not cause harm to human health. Even if we assume that drinking alcohol can "threaten danger", hemp, in the author's opinion, does less harm. Thus, the author indicates a greater degree of safety of hemp compared with tobacco and alcohol.

For this fragment of the text, the noun myth and adjective dangerous are relevant. Here the word myth is used in figurative meaning as "untrue story, fiction", therefore, the danger of marijuana for society is untrue information, fiction. And the context partners lead and maintain the component 'reliability of information' in the meaning of the word safeness. The meaning of the sentence "Actually quite the opposite" also supports this component in the meaning of the word safety. 
Naturally, the examples above are not exhaustive. Nevertheless, the examples demonstrate that there is a close, interrelationship between components of meaning and the well-organized coherent text.

"Relations between words are as important as what is in the word" [CARTER 2012, 113].

The concept is difficult and care should be taken not to discourage the student with too much technical theory initially. I draw an analogy with how my partner introduced his thirteen year old daughter to art. During her visit to London (when her interests included the London Eye, Houses of Parliament and Madame Tussauds) he negotiated one hour in the National Gallery. He selected four paintings, which he showed and talked about for a maximum of 10 minutes each. He had caught her interest and, the following year visiting Amsterdam, she requested a full morning in the Van Gogh Museum.

Our teaching experience shows that componential analysis is similar. Introduce a few 'straight-forward', interesting examples. Leave the subject. Then add more detail only as the students mature.

The effort is worthwhile. Giving the students the skills to perform a scientifically based analysis of the meaning of the word leads them to intuitively better select their words, to enrich their speech and helps elevate their dialogue to that of an educated and well spoken Russian.

\section{References:}

ALEKSANDROVA, Z.Je. (2001): Slovar' sinonimov russkogo jazyka: Okolo 11 ooo sinonimičeskich rjadov. Moskva.

CARTER, R. (2012): Vocabulary. Applied Linguistic Perspectives. Hoboken.

ČERNJAK, V.D. (1997): Sinonimičeskije svjazi slov kak predmet idiolekta. In: ČERNJAK, V.D. (red.): Aktual'nyje problemy funkcional'noj leksikologii. Sankt-Peterburg, S. $103-108$.

JEFREMOVA, T.F. (200o): Sovremennyj tolkovyj slovar' russkogo jazyka. <www. efremova.info/word/bezopasnyj.html\#.XF9aLrh7nIU> [online]. [cit. 10. 2. 2019].

KUBRJAKOVA, Je. S. (1981): Tipy jazykovych značenij. Semantika proizvodnogo slova. Moskva.

NORMAN, B. Ju. (1994): Grammatika govorjaščego. Sankt-Peterburg.

OŽEGOV, S. I., ŠVEDOVA, N. Ju. (2006): Tolkovyj slovar' russkogo jazyka: 80000 slov i frazeologičeskich vyraženij. Moskva. 
SOLGANIK, G. Ja. (2002): Stilistika teksta. Moskva.

STEPANOVA, V.V.(1998): Sub"jektnaja organizacija chudožestvennogo teksta i analiz jego leksičeskoj struktury. In: STEPANOVA, V. V. (red.): Rusistika: Lingvističeskaja paradigma konca XX veka. Sankt-Peterburg, s. 328-332.

STERNIN, I. A. (1985): Leksičeskoje značenije slova v reči. Voronež.

VALGINA, N. S. (2003): Teorija teksta. Moskva.

\section{About the author}

Marina Vazanova, Comenius University in Bratislava, Faculty of Arts, Department of Russian and East European Studies, Bratislava, Slovakia, vazanovamg@gmail.com 
